\title{
Study on EAP-based College English Course System Construction
}

\author{
Haiyan Jiang \\ Qiqihar Medical University, Qigihar Heilongjiang, 161000, China
}

Keywords: EAP, College English, Course system, Construction

\begin{abstract}
With social progress, universities pay more attention to course education. Establishment of college English course system based on EAP becomes a new development direction and important content. This paper mainly analyzes domestic and overseas EAP research achievements, and discusses the structure of EAP college English course construction and basic construction principles. To construct college English course, it is necessary to establish more scientific EAP college English course which meet students and society and make sure professional talent training demand and training objective an be fully satisfied.
\end{abstract}

\section{Introduction}

As the overall national strength keeps improving, English gradually becomes more important in China, and it is a basic tool for external exchange. Based on international development of higher education, the society pays more attention to English application ability, continuously boosts college English level and promotes English to develop towards professionalization, academy and diversification. Traditional college English teaching mode cannot meet social demand gradually. Some universities start to gradually fuse in English for Academic Purpose (EAP) to satisfy requirements of practically training academic English ability and comprehensive English application ability. College English gradually transforms to basic English learning to service-based English learning. EAP can be divided into two parts: English for Specific Academic Purpose (ESAP) and English for General Academic Purpose (EGAP). EGAP pays attention to analysis of generality of English subject, i.e. to train students' ability to apply English for written exchange and oral communication. How to rationally apply English to talk about meetings and academic English lecture and seek corresponding resources for writing? ESAP mainly aims at English subject, such as vocabulary, grammar, type of literature and article involved in finance, project, law and medicine and properly trains communication ability in actual work. The foundation of EAP is EGAP. ESAP belongs to a high form. EAP owns obvious teaching purpose. It can not just accept special learning demand, but also train the talents which conform to international form and era development demand. EAP-based college English course system construction provides important content and direction for reforming college English.

\section{Construction of EAP-based college English course system}

Since the development and establishment of college English, relevant departments have reformed teaching system repeatedly, but fail to gain the way to effectively enhance English quality of college students. The main reasons include the following: the teaching content does not comply with era development; college English textbooks lag behind; college English teaching objective deviates. Thus, in spite of reform times, English teaching way in senior high school still follows, and no breakthrough is gained. Hence, it is required to rationally reform college English teaching mode, show the reform in teaching mode and pay attention to actual content of transformation. Original teaching mode and single English teaching are transformed to the teaching mode which focuses on designing course content. EAP teaching gradually becomes a main course in universities, pays attention to training EAP ability and offers basis for further studying professional talents. 


\section{Theoretical basis of EAP college English course system}

Theoretical basis EAP mainly utilizes English language to meet actual learning demand of professional English course. Some scholars consider that learning skill is the most important skill in EAP. Under the influence of English environment, language skill is involved in training professional talents. EAP is a relatively important branch of EAP. Relevant experts summarize four features of EAP. Course design needs to completely conform to the learning purpose of special needs. When course content is designed, it is required to fully meet the requirements of specific occupation, science and activity etc. Besides, language knowledge, literary form knowledge and articles should be mastered in course design. General English should be distinctly compared in course design. Demand analysis is the core idea of EAP. Based on demand analysis, EAP can accurately analyze what students need to confirm through English. Through continuous development and progress, EAP mainly becomes a learning mode to continuously meet development demand of professional English course. When English serves as classroom learning media or course learning content, English can fully satisfy students' actual demand ${ }^{[1]}$.

During professional English ability training and college English teaching, the function and value of EAP has gained the approval of relevant scholars and experts. English teaching in middle and primary schools is to position and analyze on the basis of general English. College English teaching is mainly based on professional application. Through large-scale social demand survey several times, it is found that English is actually a communication tool, and English is used to express thought and gain the desired information. On this basis, college English belongs to ESAP. Some scholars propose to gradually reduce comprehensive English and mainly develop EAP. In 2013, Shanghai Municipality proposed that all colleges in Shanghai should transform required comprehensive English course to a optional course. The required English is defied as EAP, and the first college English guiding document is gradually established based on EAP, i.e. College English Teaching Reference Framework in Shanghai Municipality. The formation of the above guiding document not just makes Shanghai gradually connected with world universities, but also offers basis for development of EAP course in colleges. Based on this precondition, this paper mainly investigates EAP college English course system so as to promote learning exchange and development.

\section{Basic principles of EAP college English course system construction}

\section{Construction objective of individualized AP course system}

The fundamental development purpose of EAP is to fully conform to actual special demand of learners. When EAP course is set, individuation principle should be reflected and followed. Besides, it is required to continuously satisfy the demand for English talents according to individualized learning method. Under the precondition of individualized demand analysis, EAP course teaching program actually implements the course on the basis of different characteristics and types. Various colleges should formulate individualized EAP teaching schemes according to actual conditions, training objective, individualized development and specialty features. Under the precondition of such English teaching scheme, relevant specialties in colleges should set menu-type and adjustable EAP course according to development demand, pay attention to reflect initiative of EAP teaching, and provide basis for improving teaching quality so as to better analyze, guide and fully meet the demand of students with individualization development. Furthermore, professional study ability of college students should be focused on during EAP course design ${ }^{[2]}$.

Basic content of diversified development EAP course system

EAP belongs to an efficient professional English language applied by college students and, which can offer reference and basis for English teaching and promote students change senior high school learning mode to college application learning mode. It is an essential English teaching mode. Thus, the basic content of college English teaching system is EAP. EAP can be divided into two parts: ESAP and EGAP. EGAP is mainly set for freshmen and sophomores and pays attention to training students' reading, writing, listening, speaking and translation abilities. ESAP is mainly set for junior students and senior students. Large differences in teaching level,, student pool and faculty exist in 
domestic colleges and regional colleges. Oclleges need to adopt different teaching methods for EAP according to actual conditions, establish special and diversified EAP course $\mathrm{e}^{[3]}$.

Networked development of EAP course system resource

Because of social progress and development, educational technology starts to develop rapidly. Compared with traditional methods, multiple network owns more resources and information, which can offer science development trend, professional knowledge and rich resources for autonomous learning of college students. In the process of EAP course system construction, colleges should effectively refer to some excellent teaching reform achievements, such as multimedia teaching based on computer and classroom and network teaching platform. By abundant multimedia network resources, EAP course connotation can be continuously constructed and changed, provide good language environment for students and effectively solve actual problems. The special carrier of information is network. During constructing EAP course design, textbooks and teaching mode, the problems and defects may be compensated to develop students' autonomous learning ability and individualized learning method.

Scientific development of EAP course evaluation system

Effective analysis and resolution of defects and problems in course program reform is the major purpose of evaluation, which can provide new information point for course system reform, offer reference and basis for students' learning effect and course strategy, gradually cultivate students' ability to gain professional knowledge and new knowledge and apply English. This is beneficial to promoting individualized development and training interdisciplinary talents. Therefore, it is required to gradually show scientificity through diversified EAP course system, organically combine summative evaluation and formative evaluation and focus on formative evaluation so as to improve the overall evaluation system and construct main contents of $\mathrm{EAP}^{[4]}$.

\section{EAP course system}

College English is not just a course, but also a structure course system. EAP-based college English course system mainly includes three types of courses: optimal course, core course and transitional course. Transitional course belongs to optimal course. Generally speaking, the new students with low English level may learn common English course to learn English foundation and transit for future core course. Transitional courses mainly include writing, grammar, listening, speaking ad reading etc.

Core courses mainly include two parts: ESAP and EGAP. EGAP belongs to a required skill. In general, its main function is to train students' EAP ability through cross-subject. EGAP courses mainly include academic writing, academic statement, academic listening and speaking as well as academic reading etc. ESAP course is mainly set for senior class. It is rationally set according to the specialty and college, including computer English, legal English, medical English and financial English etc. ESAP is defined as the required course or optimal course according to college development.

The main purpose of college English optimal course is to enrich language culture, continuously expand students' comprehensive quality and reflect humanity in English study. Some selectable EGAP courses may set by colleges, such as scientific development and ethics, British and American culture and society as well as European and American culture and film and television appreciation. These can help students more fully know and master foreign social culture, know international development situation, master cooperation, communication, cross-science and timely communication. Besides, these can train students' tolerance and understanding of different culture, enhance sense of national identity, develop humanity and scientific literacy as well as creation and critical thinking. In other words, colleges need to rationally set college English course on the basis of conforming to classified guidance and autonomous college running, design individualized English teaching course according to students' level and specialty demand, organically combine cross-culture English course, EAP course and common English course and establish more scientific individualized English course which complies with social development ${ }^{[5]}$. 


\section{Conclusions}

In conclusion, with era development pace and development of global era, China gradually turns into an international country from a local country. The most important international communication tool is English which has been widely applied. More interdisciplinary talents with strong English ability and professional ability emerge in all industries. Thus, colleges gradually realize it is particularly important to establish English course system which conforms to era progress. In college English course design, EGAP should be transformed to ESAP, which has gained the approval of some experts. Many colleges in China implement individualized development, actively analyze and discuss EAP construction practice and theory according to their features, college-running objective and students' level and finally form college English course system based on EAP so as to promote all-round reform of college English teaching to some extent.

\section{Acknowledgement}

This paper belongs to the topic of higher education in Heilongjiang Province. Topic title: study on integrated course construction of general English and medical English; topic No.: 14G158; this paper is also the topic of Qiqihar Medical University; topic name: study on constructing EAP integrated course system and improving students' scientific research ability; topic No.: JY20141045

\section{References}

[1] Li Ning, Exploration of College English Teaching Reform Path - Analysis and Comparison Based on CBI and EAP Teaching Idea. Journal of Hubei Correspondence University, 2014(21):126-127.

[2] Zhang Ya, Lu Huaguo, Exploration of College English College English Course in Colleges of Science and Engineering - EAP. Journal of Language and Literature Studies (foreign language education and teaching), 2015(8):108-110,153.

[3] Song Haiying, EAP-oriented College English Course System Construction. Journal of Hubei University of Economics (Humanity and Social Science Edition), 2015(2):210-211.

[4] Gong Rong, Wu Chengjun, EAP Writing Teaching Design Case for Undergraduates in Research-based Universities - Concern on Trigger Mechanism of Teaching Design Ability of College Teachers. Contemporary Foreign Languages Studies, 2013(8):35-39.

[5] Chen Jiao, Zhang Yuxuan, Li Lanjie et al., Study on Connection of EAP-oriented College English and Bilingual Teaching. Theory Research, 2015(11):112-113. 